\title{
Ultrastructural Biomarkers in Symbiotic Algae Reflect the Availability of Dissolved Inorganic Nutrients and Particulate Food to the Reef Coral Holobiont
}

\author{
Sabrina Rosset ${ }^{1}$, Cecilia D'Angelo ${ }^{1,2}$ and Jörg Wiedenmann ${ }^{1,2 *}$ \\ ${ }^{1}$ Coral Reef Laboratory, Ocean and Earth Science, University of Southampton, Southampton, UK, ${ }^{2}$ Institute for Life \\ Sciences, University of Southampton, Southampton, UK
}

\section{OPEN ACCESS}

Edited by:

Eric 'Pieter Achterberg,

GEOMAR Helmholtz Centre for Ocean

Research Kiel, Germany

Reviewed by:

Christian Lønborg,

Australian Institute of Marine Science,

Australia

Arvind Singh

GEOMAR Helmholtz Centre for Ocean

Research Kiel, Germany

David Suggett,

University of Technology Sydney,

Australia

*Correspondence:

Jörg Wiedenmann

joerg.wiedenmann@noc.soton.ac.uk

Specialty section: This article was submitted to Marine Biogeochemistry, a section of the journal Frontiers in Marine Science

Received: 23 July 2015 Accepted: 09 November 2015

Published: 26 November 2015

Citation:

Rosset S, D'Angelo C and Wiedenmann J (2015) Ultrastructural Biomarkers in Symbiotic Algae Reflect the Availability of Dissolved Inorganic Nutrients and Particulate Food to the

Reef Coral Holobiont.

Front. Mar. Sci. 2:103.

doi: 10.3389/fmars.2015.00103
Reef building corals associated with symbiotic algae (zooxanthellae) can access environmental nutrients from different sources, most significantly via the uptake of dissolved inorganic nutrients by the algal symbiont and heterotrophic feeding of the coral host. Climate change is expected to alter the nutrient environment in coral reefs with the potential to benefit or disturb coral reef resilience. At present, the relative importance of the two major nutrient sources is not well understood, making predictions of the responses of corals to changes in their nutrient environment difficult. Therefore, we have examined the long-term effects of the availability of different concentrations of dissolved inorganic nutrients and of nutrients in particulate organic form on the model coral Euphyllia paradivisa. Coral and algal biomass showed a significantly stronger increase in response to elevated levels of dissolved inorganic nutrients as compared to the supply with particulate food. Also, changes in the zooxanthellae ultrastructure, determined by transmission electron microscopy (TEM), were mostly driven by the availability of dissolved inorganic nutrients under the present experimental conditions. The larger size of symbiont cells, their increased accumulation of lipid bodies, a higher number of starch granules and the fragmentation of their accumulation body could be established as reliable biomarkers of low availability of dissolved inorganic nutrients to the coral holobiont.

Keywords: dissolved inorganic nutrients, corals, symbiodinium, heterotrophic feeding, nutrient limitation, biomarker, dinoflagellates, climate change

\section{INTRODUCTION}

Coral reefs provide important ecosystem services by supporting a vast biodiversity, coastal protection and food supply for millions of coastal inhabitants. They are of substantial economic value to fisheries and the recreation and tourism industries (Moberg and Folke, 1999). Corals reefs are threatened by global warming and a broad range of human impacts (Baker et al., 2008; van Hooidonk et al., 2013; D'Angelo and Wiedenmann, 2014). Their habitat-forming scleractinian species have a certain potential to adapt/acclimatize to elevated temperatures (Logan et al., 2014) 
and regional coral populations can stand unusual levels of heat stress (Barshis et al., 2013; Hume et al., 2013). However, it is uncertain whether these temperature tolerant forms will extend their geographic range in the warming oceans since local adaptations can prevent their wider distribution (D'Angelo et al., 2015). Therefore, it is questionable whether coral reefs will deliver their ecosystem services in the future.

Shallow, warm water reefs are commonly found in oligotrophic waters where the nitrogen and phosphoruscontaining nutrients that are required to sustain cellular growth (Falkowski et al., 1984; Yellowlees et al., 2008) are scarce in both dissolved and particulate forms (Dubinsky and Jokiel, 1994; but see Szmant, 2002). The success of reef-building corals in these environments can be attributed to their symbiotic association with unicellular algae of the genus Symbiodinium (zooxanthellae). This symbiosis enables the holobiont to access both nutrient pools, dissolved inorganic and organic nutrients $\left(\mathrm{NH}_{4}^{+}, \mathrm{NO}_{3}^{-}, \mathrm{PO}_{4}^{3-}\right.$, urea, free amino acids) which can be assimilated by the zooxanthellae (D'Elia and Webb, 1977; Grover et al., 2006, 2008) and organic nutrients in particulate form which can be accessed by the host via heterotrophic feeding on zooplankton, bacteria and suspended particulate matter (Yonge, 1930; Johannes et al., 1970; Bak et al., 1998; Anthony, 2000; Heidelberg et al., 2004; Yahel et al., 2005). Additionally, the zooxanthellae acquire ammonium derived from host catabolic pathways, thereby efficiently retaining and recycling nitrogen within the holobiont (Muscatine and D'Elia, 1978; Rahav et al., 1989; Wang and Douglas, 1998). In addition, bacterial nitrogen fixation could potentially represent an additional source of nitrogen for corals as reviewed by Rädecker et al. (2015).

The limited availability of nutrients is thought to restrict the growth of zooxanthellae in hospite (Muscatine et al., 1989). While experimental evidence indicates that this limitation is mostly due to an insufficient supply with nitrogen (Fabricius, 2005; Wiedenmann et al., 2013; D'Angelo and Wiedenmann, 2014), a limited availability of phosphorus has also been suggested to constrain algal proliferation (Rands et al., 1993; Yellowlees et al., 2008). The nutrient-limited zooxanthellae in shallow water corals in oligotrophic environments experience an often sufficient exposure to photosynthetic active radiation (Dubinsky and Jokiel, 1994). While $\mathrm{CO}_{2}$ supply for the algal cells is not unlimited in these corals (Muscatine et al., 1989), it seems to be less limiting than the nutrient availability given that photosynthesis and carbon fixation are largely uncoupled from cellular growth as indicated by the transfer of substantial amounts of photosynthetically fixed carbon from the zooxanthellae to the host (Falkowski et al., 1993; Dubinsky and Jokiel, 1994). This carbon transfer can help the algae to maintain a favorable chemical balance (Falkowski et al., 1993; Dubinsky and Jokiel, 1994). The coral host benefits from the translocated photosynthates which support energy and mucus production (Muscatine, 1965; Falkowski et al., 1984; Crossland, 1987; Bachar et al., 2007).

The capacity of the symbiotic algae to assimilate dissolved inorganic nutrients renders them sensitive to changes in environmental nutrient levels (Muscatine et al., 1989) and these disturbances can directly increase the susceptibility of corals to bleaching, the often fatal breakdown of the symbiotic association (Wiedenmann et al., 2013; Cunning and Baker, 2013; Vega Thurber et al., 2014). In particular, phosphate starvation of zooxanthellae which can result from imbalanced nitrate enrichment has been shown to reduce the threshold for heat and light stress-mediated bleaching (Wiedenmann et al., 2013). Dissolved inorganic nutrient deprivation resulting from competition with other organisms such as blooming phytoplankton was also suggested as a potential cause for increased susceptibility of corals to thermal bleaching (D'Angelo and Wiedenmann, 2014). In contrast, supplementation with inorganic nitrogen and particulate food has the potential to mitigate negative effects of heat stress on zooxanthellae photosynthesis (Hoogenboom et al., 2012; Béraud et al., 2013). The supply with nutrients via heterotrophic feeding of the host has also been shown to promote coral recovery after episodes of bleaching (Grottoli et al., 2006).

Global change-driven modification of the nutrient environment is likely to affect coral reefs due to (A) the increased nutrient enrichment of coastal waters and associated negative effects due to human population growth and the intensified use of coastal areas (D'Angelo and Wiedenmann, 2014) and (B) the nutrient impoverishment of oceanic waters due to stronger stratification of the water column promoted by warming surface waters (Behrenfeld et al., 2006). The latter conditions prevailed during the 1997/98 coral die-off at Galapagos when the El Niño Southern Oscillation (ENSO)-mediated reduction of major upwelling resulted in nutrient deficiency (Chavez et al., 1999) and an associated drop in surface water productivity in combination with exceptionally high water temperatures (Riegl et al., 2015). Such a reduction in productivity can also result in a decrease of zooplankton biomass (Roemmich and McGowan, 1995; Chust et al., 2014), further depriving corals from vital nutrients by impairing heterotrophic feeding. Therefore, future changes in nutrient fluxes in coral reefs in oceanic environments may act in combination with increased heat stress levels (Logan et al., 2014) to accelerate reef decline. In contrast, the higher food availability in coastal waters that may result from the expected nutrient-fueled increase in primary production could result in a trophic shift to predominantly heterotrophic coral communities (Anthony and Fabricius, 2000) and possibly mitigate some of the direct negative effects of nutrient enrichment on coral physiology (D’Angelo and Wiedenmann, 2014). However, it is yet unclear whether the potentially beneficial (Grottoli et al., 2006) or adverse (Fabricius et al., 2013) effects of greater food abundance on reef corals will dominate in the future. In particular, the interactive effects of host feeding in combination with high or low availability of dissolved inorganic nutrients on the physiology of the coral holobiont are not well understood.

Many previous studies focused either on the effects of enrichment with dissolved inorganic nutrients without controlling feeding (Stambler et al., 1991; Marubini and Davies, 1996; Ferrier-Pagès et al., 2000), or analyzed the effects of feeding without comparative investigation of the dissolved inorganic nutrient enrichment (Muller-Parker et al., 1996; Houlbrèque et al., 2004; Hoogenboom et al., 2010; Tolosa et al., 
2011; Tremblay et al., 2014). Studies that did consider both nutrient sources, subjected corals to short-term treatments ranging from 2 to 4 weeks (Muscatine et al., 1989; Dubinsky et al., 1990; Smith and Muscatine, 1999; Titlyanov et al., 2000). However, since some physiological responses of corals to changes in environmental conditions such as the photoacclimation of the host can take up to 6 weeks to reach a fully acclimated state (Gittins et al., 2015), long-term experiments are required to define endpoints in the acclimation process. Biomarkers of such acclimation responses hold high potential to serve as indicators of changes in nutrient environments in coral reef waters which are otherwise difficult to detect due to rapid uptake and turnover of dissolved inorganic nutrients by pelagic communities (Furnas et al., 2005).

We have therefore assessed the combined effects of the availability of dissolved inorganic nutrients and particulate food on the performance of the coral holobiont. Long-term experiments were conducted in which the corals together with their symbionts were exposed to different nutrient environments for $>1.5$ years. We used transmission electron microscopy (TEM) to examine the ultrastructure of the algal symbionts and to establish biomarkers reflecting the nutrient environment. The results of our study provide novel insights into the complex nutrient physiology of the coral-Symbiodinium association.

\section{METHODS}

\section{Model Corals and Experimental Set-up}

Euphyllia paradivisa is widely distributed in the central Indopacific, American Samoa and the Red Sea. It is characterized by large polyps and long tentacles which enable the coral to take up comparably large food items. The tentacles can be easily removed and yield high quality zooxanthellae preparations due to the lack of contamination by skeletal remains. Hence, E. paradivisa represents an excellent model species to study the effects of heterotrophic feeding (D'Angelo and Wiedenmann, 2012). The corals were cultured in the experimental mesocosm of the Coral Reef Laboratory at the National Oceanography Centre Southampton (D'Angelo and Wiedenmann, 2012). The experimental units were maintained at high nutrient (HN) $\left(\mathrm{NO}_{2}^{-} / \mathrm{NO}_{3}^{-} \sim 6.5 \mu \mathrm{M}\right.$ /phosphate $\sim 0.3 \mu \mathrm{M}$ ) or low nutrient (LN) $\left(\mathrm{NO}_{2}^{-} / \mathrm{NO}_{3}^{-} \sim 0.7 \mu \mathrm{M} /\right.$ phosphate $\left.\sim 0.006 \mu \mathrm{M}\right)$ levels, conditions which were previously established to simulate nutrient replete and nutrient limited environments, respectively (D'Angelo and Wiedenmann, 2012; Wiedenmann et al., 2013). Ammonium levels $\left(\mathrm{NH}_{4}^{+}\right)$measured in the experimental aquarium system were very low $(<0.7 \%$ of total dissolved inorganic nitrogen, DIN) compared with the combined $\mathrm{NO}_{2}^{-}(\sim 10 \%)$ and $\mathrm{NO}_{3}^{-}$ concentrations $(\sim 90 \%)$. Therefore, DIN was considered to be represented by $\mathrm{NO}_{2}^{-}$and $\mathrm{NO}_{3}^{-}$values (Wiedenmann et al., 2013). Polyps of selected replicate colonies from both nutrient conditions were individually fed three times per week with defined portions of prawn muscle tissue (one portion $=\sim 2.15 \mathrm{mg}$ dry weight, $\sim 4.83 \mathrm{cal})$. Fed and unfed colonies were cultured side by side within the respective experimental tanks to ensure that they experienced identical conditions apart from the deviating feeding regime. The services of a commercial provider (Eurofins) were used to determine the nutrient content of the food. A single portion offered to a polyp per feeding event contained $\sim 170 \mu \mathrm{g} \mathrm{N}$ and $\sim 6.9 \mu \mathrm{g}$ P. The amount of particulate food used in the experiments falls in the order of magnitude discussed to be available to corals in the natural environment (Johannes et al., 1970; Heidelberg et al., 2004; Yahel et al., 2005). To test satiation threshold of the corals exposed to different nutrient environments, feeding was increased to five times per week. Food intake was measured as the percentage of polyps that ingested the offered portions. Food that was not taken up by the polyps within $30 \mathrm{~min}$ was removed from the tank and recorded. Corals were cultured at a constant temperature of $25^{\circ} \mathrm{C}$ and a photonflux of $\sim 150 \mu \mathrm{mol} \mathrm{m} \mathrm{m}^{-2} \mathrm{~s}^{-1}$ with a $10 / 14 \mathrm{~h} \mathrm{light/dark}$ cycle. Four experimental treatments were established: HN/unfed; HN/fed; LN/unfed; and LN/fed. Polyps were cultured under these conditions for over 1.5 years prior to sampling.

\section{Symbiodinium spp. Phylotyping}

Tentacles of E. paradivisia were harvested, sonicated for $15 \mathrm{~min}$ in deionized water (MilliQ, Millipore) water and homogenized using a micropestle. Zooxanthellae were separated from tissue homogenate by five consecutive centrifugation $(2500 \mathrm{~g})$ and wash steps with sterile-filtered seawater. Genomic DNA was extracted and the Symbiodinium spp. ribosomal DNA section, covering partial $18 \mathrm{~S}$, full ITS1, 5.8 S, and ITS2, and partial $28 \mathrm{~s}$ regions, was amplified by PCR using the protocols and primers described in Hume et al. (2013). The PCR product was cloned using StrataClone PCR cloning kit (Aligent Technologies). Plasmid DNA was purified using a QIAprep Spin miniprep kit (Qiagen). Sequencing was performed by Macrogen. Symbiodinium spp. subclade C1 was identified by comparing the ITS2 region $(220 \mathrm{bp})$ with reference sequences by BLAST searches (www.ncbi.nlm.nih.gov/blast).

\section{Polyp Biomass and Protein Content}

Five polyps were collected from colonies exposed to each of the experimental conditions. The polyp was cut off at the border between live tissue and exposed skeleton using a hacksaw. Polyps were allowed to drip-off for $2 \mathrm{~min}$ on absorbent tissue. Their weight was then determined and the individual polyps were transferred into $50 \mathrm{ml}$ Falcon tubes with $10 \mathrm{ml}$ MilliQ water. The polyps were homogenated using a pestle and vigorous shaking. The homogenate was adjusted to $20 \mathrm{ml}$ with MilliQ water. The samples were subsequently centrifuged for $10 \mathrm{~min}$ at $2500 \mathrm{~g}$, the supernatant was transferred to a clean tube and the volume of homogenate was determined. Aliquots $(2 \mathrm{ml})$ were removed and centrifuged at $20000 \mathrm{~g}$. The supernatant was used to measure host protein content using the BCA protein assay following the protocols from the manufacturers (PierceThermo Scientific, USA). The protein content of the individual polyps was calculated by multiplying the protein concentration of the subsamples with the total recovered volume of tissue homogenate. 


\section{Transmission Electron Microscopy Sample Preparation}

The polyps of E. paradivisia showed a tendency to contract toward the end of the dark period and expanded again at the beginning of the light period. Since a full expansion of the polyps facilitates the harvest of samples of comparable size, tentacles were collected within the first hour of the light period. Per experimental condition, three tentacles were sampled, each of them being removed from a different colony. Tentacles were chosen which were well-exposed to light and located around the center of the polyp. Samples were fixed for $1 \mathrm{~h}$ in $3 \%$ glutaraldehyde, $4 \%$ formaldehyde, and $14 \%$ sucrose in $0.1 \mathrm{M}$ PIPES buffer at $\mathrm{pH}$ 7.2. The central section of the fixed tentacles was cut out with a razor blade and used for downstream analyses. Post fixation of specimens was performed with $1 \%$ osmium tetroxide followed by staining with $2 \%$ uranyl acetate, dehydration with a graded ethanol series, and embedding in Spurr's resin. Blocks were sectioned using an ultra microtome and the samples were mounted on $200 \mathrm{Cu}$ grids. For each tentacle, 3-5 thin sections ( $<100 \mathrm{~nm}$ thick) were obtained, each from a different region of the specimen to avoid imaging the same algal cell twice. Grids were stained with lead citrate for $5 \mathrm{~min}$. Further sections ( $\sim 500 \mathrm{~nm}$ ) were prepared for light microscopy analyses.

\section{Electron Micrograph Acquisition}

Imaging was performed on a Hitatchi H7000 transmission electron microscope. A minimum of 30 zooxanthellae cell sections were imaged, using three or more cut sections per tentacle. The 3-4 cells with the largest visible diameter per grid square were selected for imaging to ensure that the imaged cell cross-section was as close as possible to the center of the cell. A total of 100 micrographs of individual zooxanthellae (x6000 magnification) were analyzed for each condition. Additionally, 9 micrographs per condition were taken at x1000 magnification.

\section{Micrograph Analysis}

Each imaged cell was analyzed using Fiji (Schindelin et al., 2012) to determine the area of the cell section and the area occupied by chloroplasts, lipid bodies, pyrenoid starch sheath, pyrenoid core, and the accumulation body. Additionally, the number of starch granules per cell as well as the number of breaks in the outer border of each accumulation body was counted. The area of lipid bodies was expressed as percentage of the total cell section area. The pyrenoid and the accumulation body were not visible in each micrograph, especially in LN samples due to the larger cell size. The number of analyzed structures is indicated in the legend to Figure 3. The size of the pyrenoid starch sheath was only considered when the pyrenoid stalk was visible to reduce bias caused by the position of the section through the pyrenoid. Chloroplasts were analyzed in 20 randomly chosen micrographs per treatment.

Zooxanthellae density was estimated by point counting in areas of known size, using micrographs at x1000 magnification as well as semi-thin sections viewed with a light microscope.

\section{Statistical Analysis}

Data was tested for normality using the Shapiro-Wilk test and for equal variance using Levene's test. Data that was not normally distributed was log transformed prior to further testing. For the statistical analysis of zooxanthellae cell size, chloroplasts, pyrenoid starch sheath, pyrenoid core, lipid bodies, and accumulation body size, results from all micrographs were pooled as one population (Table S1). Thus, replication was achieved by the analysis of individual algal cells obtained from tentacles of different colonies and from within different regions of each tentacle, subject to comparable sampling schemes. For the analysis of the number of starch granules per algal cell and the number of breaks in the outer border of each accumulation body, means were taken from each of the three processed tentacles per treatment (Table S2). Statistically significant effects induced by the differences in the nutrient environment were determined by a Two-way analysis of variance (ANOVA) with the two factors being: dissolved inorganic nutrient availability and heterotrophic feeding (Table S3). This was followed by a Tukey's Test for pairwise comparison (Table S4). For data that did not meet the assumptions required for a two-way ANOVA after transformation, the non-parametric Scheirer-Ray-Hare test was applied. $P<0.05$ was considered to be significant in all instances.

\section{RESULTS}

\section{Effects of Nutrient Availability on the Coral Biomass}

Exposure to experimental treatments was conducted for $>1.5$ years, ensuring that our results reflect the fully acclimated state of the coral-zooxanthellae symbiosis. Polyps of E. paradivisa corals hosting Symbiodinium Clade C1 kept at high levels of dissolved inorganic nutrients $(\mathrm{HN})$ were visibly larger than those kept at low levels of dissolved inorganic nutrients (LN) (Figures 1A,B). Heterotrophic feeding did not modify the appearance of corals in the HN treatment. At LN levels, however, feeding resulted in increased polyp biomass and protein content per polyp as compared to unfed specimens (Figure 1C).

Corals from the $\mathrm{HN}$ conditions were visibly darker as compared to the LN treatment (Figures 1A,B) due to significantly higher zooxanthellae densities (Figure 1D). In contrast, heterotrophic feeding had no significant effect on zooxanthellae density, independent from the availability of dissolved inorganic nutrients in the water.

Notably, while corals from the $\mathrm{HN}$ and $\mathrm{LN}$ treatments were offered the same amount of particulate food, the food uptake varied among the two conditions. Under LN availability, $100 \%$ of the polyps ingested the food portions offered to them whereas $\sim 30-40 \%$ of the polyps of $\mathrm{HN}$ corals rejected the food (Figure 1E).

\section{Effects of Nutrient Availability on the Ultrastructure of Zooxanthellae}

The zooxanthellae ultrastructure was analyzed using TEM (Figures 2, 3). Compared to zooxanthellae from HN corals, the 
A

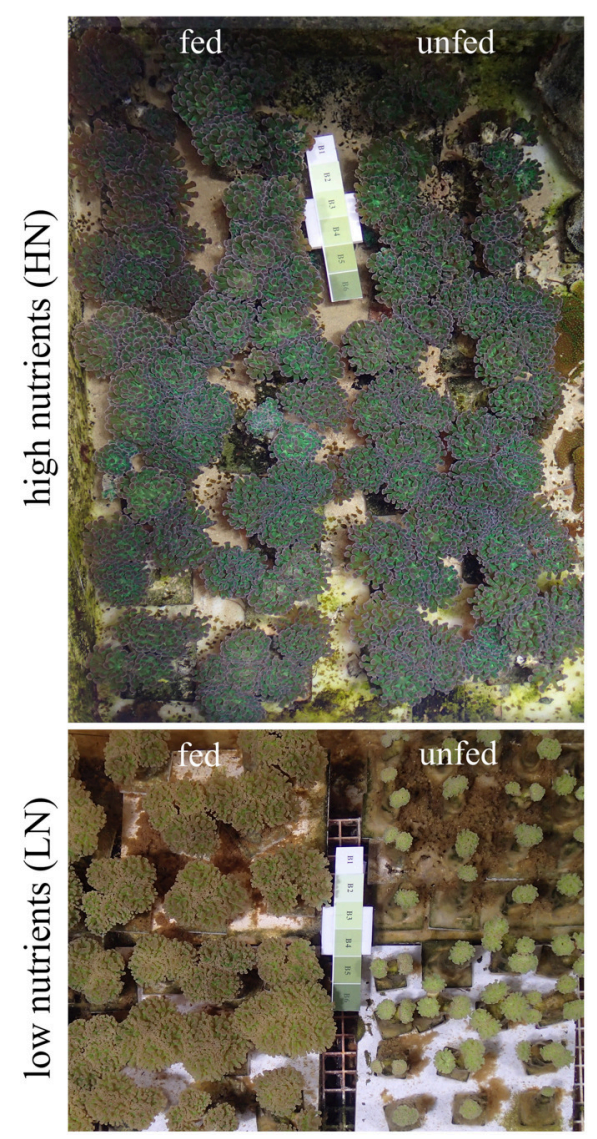

B

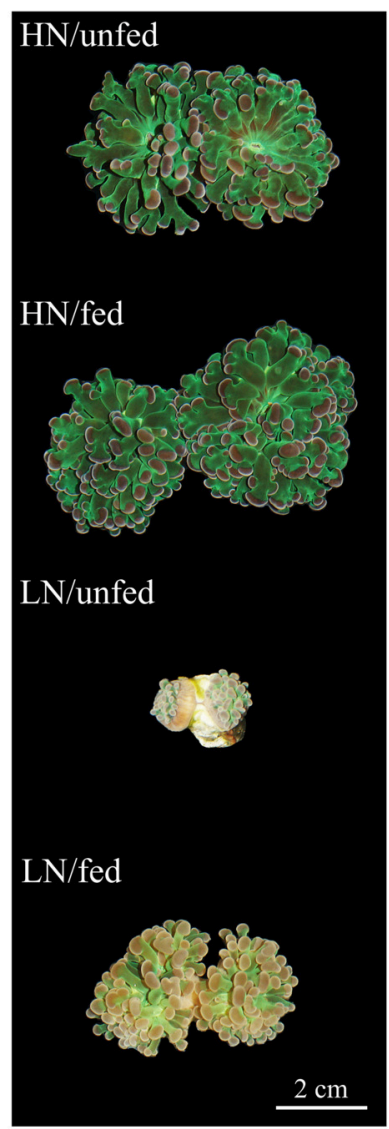

C

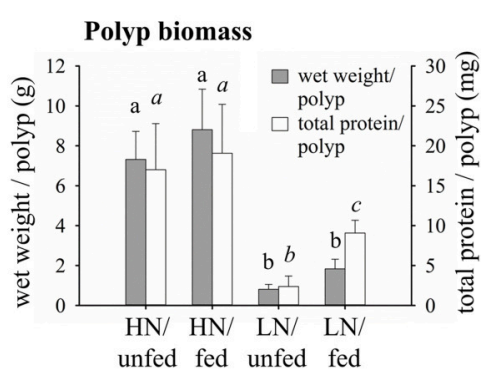

D

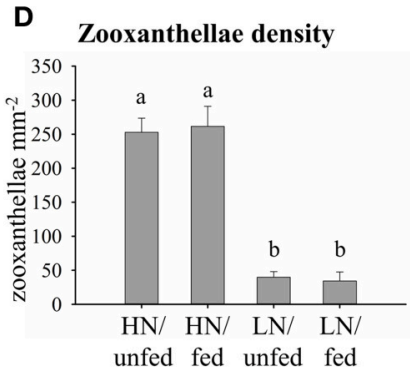

E

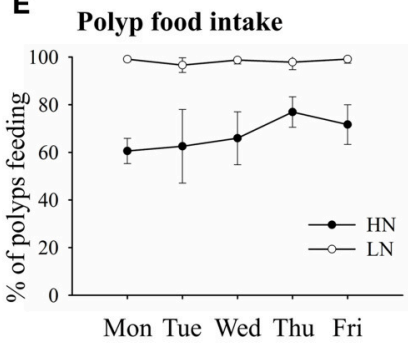

FIGURE 1 | Effects of the dissolved inorganic nutrient availability and heterotrophic feeding on E. paradivisa polyp biomass, zooxanthellae density, and feeding behavior. (A) Photographs of corals cultured under high or low availability of dissolved inorganic and particulate organic nutrients. (B) Close ups of individual polyps. (C) Wet weight and total protein content of whole polyps (HN/unfed $n=5$, HN/fed $n=4$, LN/unfed $n=4$, LN/fed $n=5$ ). (D) Zooxanthellae cell density per $\mathrm{mm}^{2}$ of $\sim 500 \mathrm{~nm}$ thick tentacle sections $(n=4)$. (E) Daily food intake of polyps measured as per cent of polyps feeding $(n=4)$. Data are presented as mean and standard deviation. Different letters indicate statistically significant differences among treatments.

size of algal cells was significantly larger in the LN treatment, with feeding resulting in a further increase under this condition (Figures 2, 3A), Neither the availability of dissolved inorganic nutrients nor host feeding affected the abundance of chloroplasts within the zooxanthellae or the extension of the starch sheath surrounding the pyrenoid (Figures $\mathbf{3 B}, \mathbf{C}$ and Figure S1). The pyrenoid core, in contrast, was significantly larger in algal cells of the $\mathrm{LN} /$ fed treatment as compared to the other treatments (Figure 3D).

Lipid body accumulation increased significantly in zooxanthellae kept under LN conditions and was further enhanced when the LN corals were fed (Figure 3E and Figure $\mathrm{S} 1)$. Also, starch granules were more abundant in zooxanthellae from LN corals compared to $\mathrm{HN}$ samples (Figure 3F). A statistically insignificant increase in starch granule accumulation was detected in response to host feeding irrespective of availability of dissolved inorganic nutrients.

The size of the accumulation body did not respond to the difference in nutrient availability (Figure 3G) but it showed a striking fragmentation in a significantly higher amount of algal cells from LN corals (Figure $3 \mathbf{H}$ and Figure S1). This fragmentation response was unaffected by the feeding regime of the corals.

\section{DISCUSSION}

We have conducted the first long-term study of the combined effects of different dissolved inorganic nutrient concentrations and particulate food availability on the reef coral holobiont in order to establish biomarkers of the respective conditions.

\section{Effects of Nutrient Availability on the Coral Biomass}

We found that the polyp biomass and the protein content per polyp were higher in $\mathrm{HN}$ corals compared to corals exposed to low dissolved inorganic nutrient levels. Zooxanthellae densities were also increased by the $\mathrm{HN}$ treatment but they were not affected by heterotrophic feeding. The access to nutrients in 


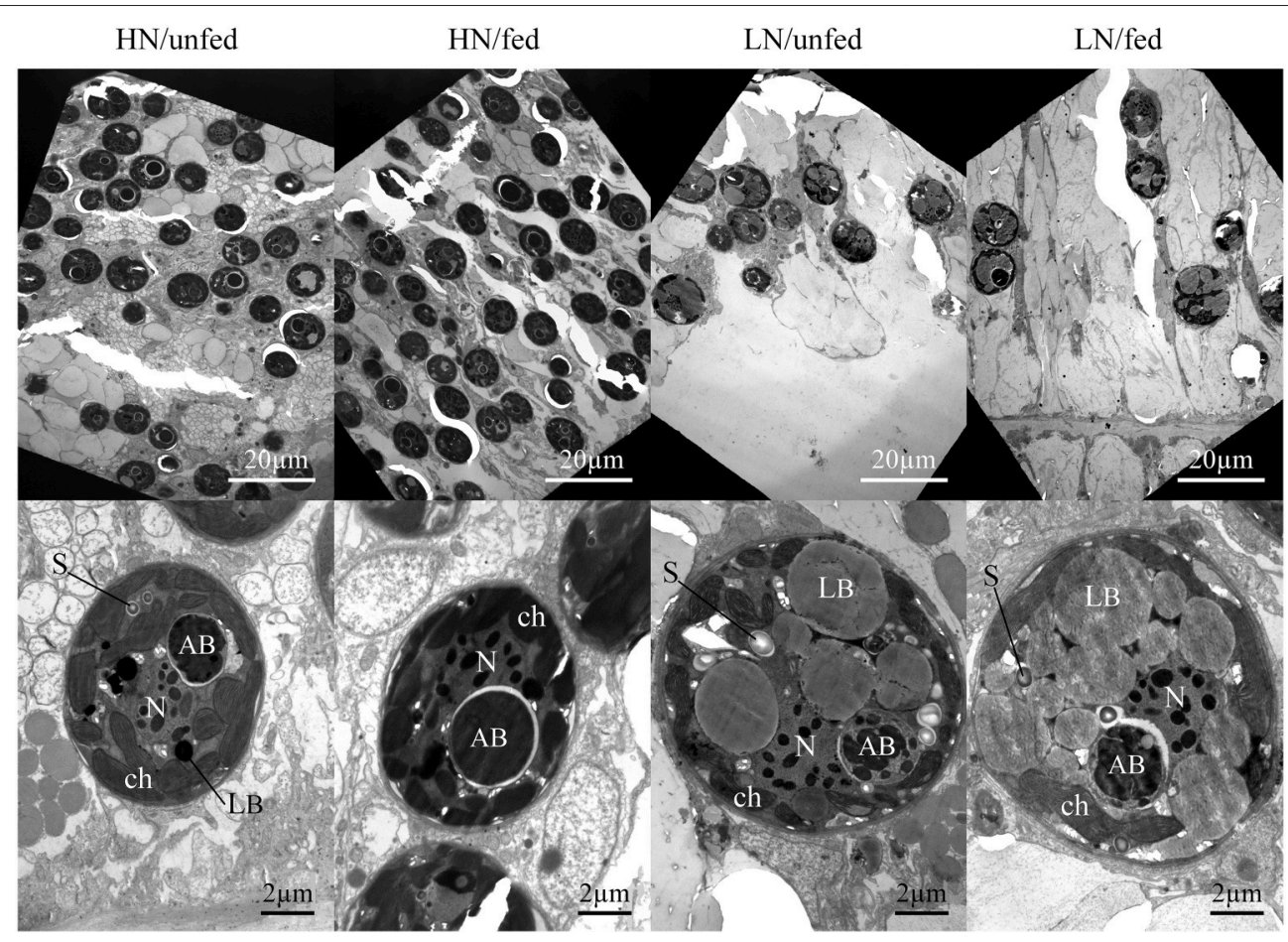

FIGURE 2 | Effects of the dissolved inorganic nutrient concentration and heterotrophic feeding on zooxanthellae population density and ultrastructure in hospite. Representative micrographs of tentacle sections showing the zooxanthellae population within the host endoderm (magnification $\times 1000$, top panels) and zooxanthellae cell sections representing the mean ultrastructure resulting from each nutrient treatment (magnification x6000, lower panels). AB, accumulation body; ch, chloroplast; LB, lipid body; N, nucleus with condensed chromosomes; P, pyrenoid; S, starch granule.

particulate form only increased the polyp protein content under $\mathrm{LN}$ conditions and to a much lesser extent as the access to $\mathrm{HN}$ levels. Hence, our results indicate that high amounts of dissolved inorganic nutrients, accessible to the coral holobiont mostly via the symbionts (Crossland and Barnes, 1977; D'Elia and Webb, 1977; Yellowlees et al., 2008; Godinot et al., 2009), can provide substantial benefits to the coral host. This is further supported by the reduced food ingestion rates of HN polyps, since lower prey capture rates can indicate satiety of corals (Ferrier-Pagès et al., 2003).

Our results suggest that nitrogen and phosphorus acquired through dissolved inorganic nutrient assimilation become available to the coral host in significant amounts and are used to promote its growth. Clearly, under the present experimental conditions, the supply of dissolved inorganic nutrients appears to be more important than the access to particulate food for the gain of biomass of the coral holobiont, suggesting a substantial translocation of nitrogen-containing compounds from the symbiont to the host (Wang and Douglas, 1999; Tanaka et al., 2006; Pernice et al., 2012; Béraud et al., 2013; Kopp et al., 2013). However, it remains uncertain how the dissolved inorganic nutrients were partitioned and allocated within the HN-exposed holobiont. A transfer to the host might occur by means of (A) translocation of nitrogen- and phosphorus-rich molecules to the host (Pernice et al., 2012), or (B) digestion of the zooxanthellae (Titlyanov et al., 2006).
Considering the response of the zooxanthellae density to nutrient availability, similar observations have been reported for Stylophora pistillata, in which daily host feeding with Artemia salina nauplii in natural, oligotrophic sea water resulted in a smaller increase in zooxanthellae densities compared to dissolved inorganic enrichment $\left(20 \mu \mathrm{M} \mathrm{NH}_{4}^{+}+2 \mu \mathrm{M} \mathrm{PO}_{4}^{3-}\right)$ (Muscatine et al., 1989; Dubinsky et al., 1990).

\section{Effects of Nutrient Availability on the Ultrastructure of Zooxanthellae}

Our TEM analysis of the zooxanthellae ultrastructure revealed that symbionts from LN corals had increased cell sizes and larger accumulations of energy storage bodies (lipid bodies and starch granules). Comparable changes in cellular characteristics were previously described for free-living microalgae (Hu et al., 2008 and references therein; Msanne et al., 2012) and zooxanthellae under nutrient limitation (Hoegh-Guldberg, 1996; Muller-Parker et al., 1996; Weng et al., 2014). Specifically, increased cell volumes have been observed for nitrogen-deprived zooxanthellae in culture (Jiang et al., 2014) and in the free-living dinoflagellate Heterocapsa sp. (Latasa and Berdalet, 1994). The increase in cell size under nutrient limitation may be associated with a decreased cell division rate (Vaulot et al., 1987).

An accumulation of neutral lipids and starch granules in zooxanthellae from LN corals is also in line with previous observations (Berner and Izhaki, 1994; Hoegh-Guldberg, 1996; 


\section{A}

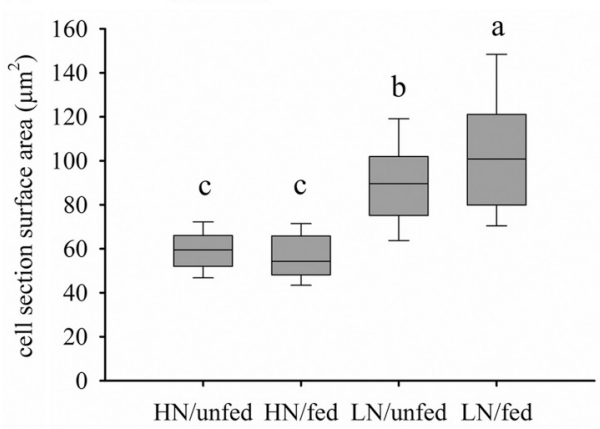

C

Pyrenoid starch sheath

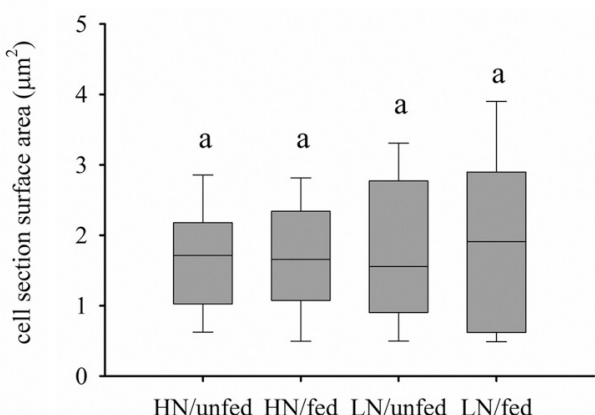

E

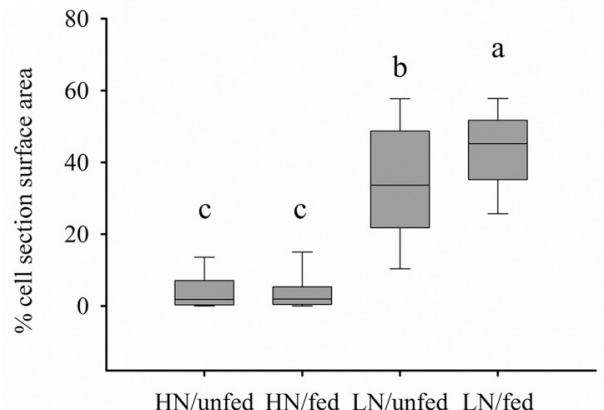

G

Accumulation body size

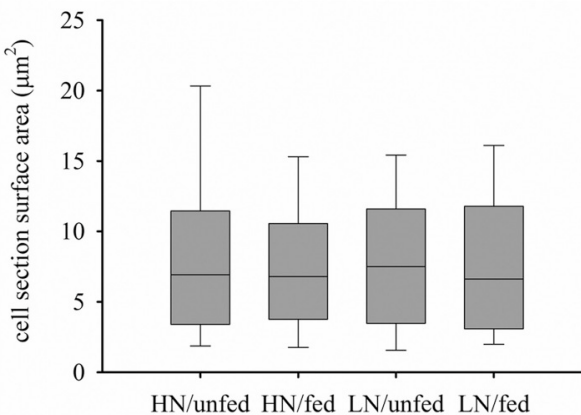

Chloroplasts

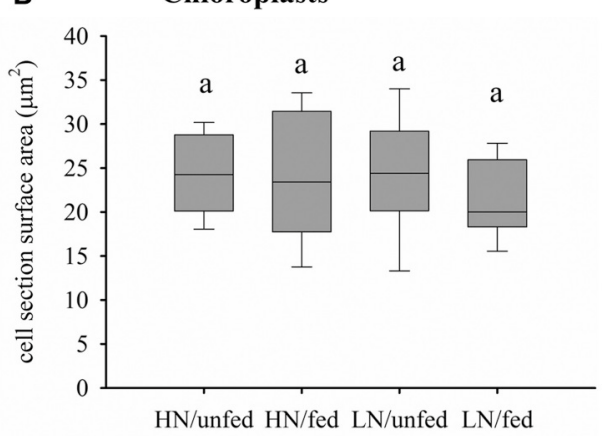

D Pyrenoid core

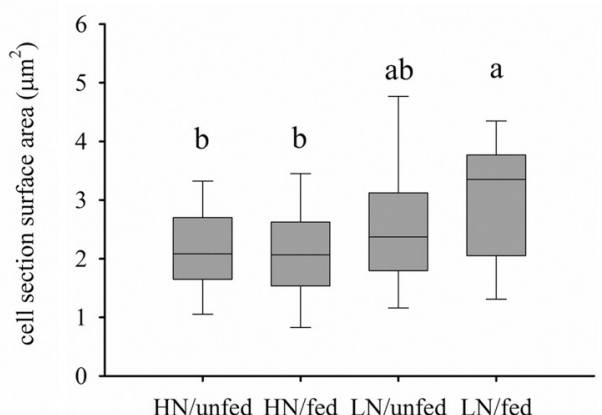

$\mathbf{F}$
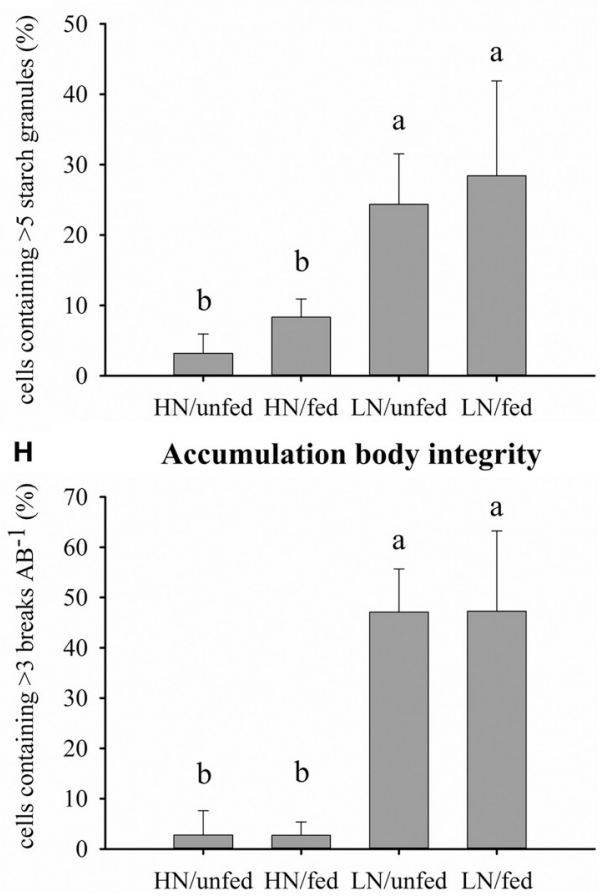

FIGURE 3 | Effects of the dissolved inorganic nutrient concentration and heterotrophic feeding on zooxanthellae cellular morphology. (A) Cell size measured as zooxanthellae section surface area $\left(\mu \mathrm{m}^{2}\right)(n=100)$. (B) Chloroplast abundance measured as section surface area ( $\left.\mu \mathrm{m}^{2}\right)(n=20)$. (C) Accumulation of starch around the pyrenoid measured as section surface area ( $\left.\mu \mathrm{m}^{2}\right)$ (HN/unfed $n=38, \mathrm{HN} / \mathrm{fed} n=32, \mathrm{LN} / \mathrm{unfed} n=22$, LN/fed $\left.n=18\right)$. (D) Size of pyrenoid core measured as cell section surface area $\left(\mu \mathrm{m}^{2}\right)$ ( $n=$ same as $\left.\mathbf{C}\right)$. (E) Accumulation of lipid bodies measured as per cent of cell section surface area $(n=100)$. (F) Abundance of starch granules represented as per cent of cells containing greater than five starch granules $(n=3)$. (G) Size of accumulation body measured as section surface area $\left(\mu \mathrm{m}^{2}\right)(\mathrm{HN} /$ unfed $n=75, \mathrm{HN} / \mathrm{fed} n=81, \mathrm{LN} /$ unfed $n=39, \mathrm{LN} / \mathrm{fed} n=46)$. (H) Accumulation body integrity measured as the per cent of accumulation bodies containing greater than three breaks within their periphery $(n=3)$. Box plots: the vertical line within each box represents the median. The box extends from the first to the third quartile and whiskers extend to the smallest and largest non-outliers. Outliers are not shown. Bar charts represent mean and SD. Statistically significant differences of pairwise comparison (Tukey's post-hoc) are indicated by the use of different letters. 
Muller-Parker et al., 1996; Weng et al., 2014). Such an increase in carbon-rich storage products could result from the uncoupling of carbon fixation from cellular growth (i.e., high photosynthetic production) in combination with a reduced energy demand of the nutrient limited cells (Hu et al., 2008; Vitova et al., 2015).

The accumulation body, a cellular compartment thought to accumulate cellular waste products (Taylor, 1968), showed an unusual, fragmented appearance in a significantly increased amount of algal cells from LN corals as compared to those from $\mathrm{HN}$ exposure, which qualifies as a novel indicator of nutrient limitation in zooxanthellae.

None of the ultrastructural changes indicative for zooxanthellae from LN corals (increases in cell size, in numbers/extent of lipid, and starch bodies and in the frequency of accumulation body fragmentation) were reduced by heterotrophic feeding, hence nutrients acquired through feeding were not sufficient at alleviating the nutrient stress imposed by the LN treatment. On the contrary, there was a slight trend for these markers to be further increased in zooxanthellae from fed LN corals, suggesting that feeding may even aggravate the algal nutrient limitation under the present experimental conditions, an observation that calls for further study.

The amount of food offered to the corals was within the range discussed to be available to corals in various reef settings (Johannes et al., 1970; Heidelberg et al., 2004; Yahel et al., 2005). However, the $100 \%$ uptake rate of LN corals suggests that they were not fed to satiation (Figure 1E). Therefore, more pronounced responses might result from an increased food supply even if such high prey availability appears unrealistic under natural conditions. On the other hand, the nutritious value of the offered food might have been inadequate, an aspect that should be analyzed in depth by future studies on heterotrophic feeding.

While corals show some plasticity in acquiring nutrients from different sources (Anthony and Fabricius, 2000; Grottoli et al., 2006; Borell and Bischof, 2008; Ferrier-Pagès et al., 2010; Connolly et al., 2012), our results assign a crucial importance to the uptake of dissolved inorganic nutrients for the performance of both the host and the zooxanthellae. This strong dependence can help to explain positive effects of dissolved inorganic nutrient availability on corals (Bongiorni et al., 2003) as well as negative responses to nutrient starvation as observed under skewed $\mathrm{N}: \mathrm{P}$ ratios (Wiedenmann et al., 2013; D'Angelo and Wiedenmann, 2014).

The findings of our study indicate that despite their symbiotic life style, zooxanthellae show responses to nutrient limitation in the water column comparable to free-living algae (Hu et al., 2008; Msanne et al., 2012). Thereby, our results highlight the limited

\section{REFERENCES}

Anthony, K. (2000). Enhanced particle-feeding capacity of corals on turbid reefs (Great Barrier Reef, Australia). Coral Reefs 19, 59-67. doi: $10.1007 / \mathrm{s} 003380050227$

Anthony, K. R. N., and Fabricius, K. E. (2000). Shifting roles of heterotrophy and autotrophy in coral energetics under varying turbidity. J. Exp. Mar. Biol. Ecol. 252, 221-253. doi: 10.1016/S0022-0981(00)00237-9 capacity of the coral host to fully isolate the symbionts from the influence of the chemistry of the surrounding seawater.

The analysis of the ultrastructural biomarkers confirmed our observations at the macroscopic level that the corals were more affected by the supply of dissolved inorganic nutrients than by the uptake of particulate food. This supports the notion that the nutrient status of the symbionts in hospite is strongly dependent on the uptake of dissolved inorganic nutrients (Dubinsky and Jokiel, 1994).

These conclusions, however, cannot be taken as support for the assumption that (anthropogenic) nutrient enrichment will generally benefit coral reefs (D’Angelo and Wiedenmann, 2014) but call for further analyses of the effects that the global/climate change-mediated alteration of the nutrient environment will have on reef ecosystems (D’Angelo and Wiedenmann, 2014; Riegl et al., 2015). Due to the fast uptake and turnover of dissolved inorganic nutrients in coral reef waters, it is difficult to establish the prevailing nutrient conditions for reef monitoring purposes solely by analysing the water chemistry (Furnas et al., 2005). In addition, high-content biomarkers are required to inform coral reef management about disturbances of the natural nutrient environment (D'Angelo and Wiedenmann, 2014). The novel biomarkers indicative of the nutrient status of zooxanthellae established in the present paper have a high potential for environmental monitoring applications since they enable to discriminate responses to different nutrient sources at the cellular and subcellular level and reflect the nutrient exposure history.

\section{ACKNOWLEDGMENTS}

We thank the Biomedical Imaging Unit University of Southampton (Anton Page) for the access to the TEM and Dr Tony Stead (School of Biological Sciences, Royal Holloway) for discussing zooxanthellae micrographs. The study was funded by NERC (NE/K00641X/1 to JW), European Research Council under the European Union's Seventh Framework Programme (FP/2007-2013)/ERC Grant Agreement n. 311179 to JW and a Vice Chancellor Award studentship to JW. We thank Tropical Marine Centre (London) and Tropic Marin (Wartenberg) for sponsoring the Coral Reef Laboratory at the University of Southampton.

\section{SUPPLEMENTARY MATERIAL}

The Supplementary Material for this article can be found online at: http://journal.frontiersin.org/article/10.3389/fmars. 2015.00103

Bachar, A., Achituv, Y., Pasternak, Z., and Dubinsky, Z. (2007). Autotrophy versus heterotrophy: the origin of carbon determines its fate in a symbiotic sea anemone. J. Exp. Mar. Biol. Ecol. 349, 295-298. doi: 10.1016/j.jembe.2007.05.030

Bak, R., Joenje, M., de Jong, I., Lambrechts, D., and Nieuwland, G. (1998). Bacterial suspension feeding by coral reef benthic organisms. Mar. Ecol. Prog. Ser. 175, 285-288. doi: 10.3354/meps 175285 
Baker, A. C., Glynn, P. W., and Riegl, B. (2008). Climate change and coral reef bleaching: an ecological assessment of long-term impacts, recovery trends and future outlook. Estuar. Coast. Shelf Sci. 80, 435-471. doi: 10.1016/j.ecss.2008.09.003

Barshis, D. J., Ladner, J. T., Oliver, T. A., Seneca, F. O., Traylor-Knowles, N., Palumbi, S.R., et al. (2013). Genomic basis for coral resilience to climate change. Proc. Natl. Acad. Sci. U.S.A. 110, 1387-1392. doi: 10.1073/pnas. 1210224110

Behrenfeld, M. J., O’Malley, R. T., Siegel, D. A., McClain, C. R., Sarmiento, J. L., Feldman, G. C., et al. (2006). Climate-driven trends in contemporary ocean productivity. Nature 444, 752-755. doi: 10.1038/nature05317

Béraud, E., Gevaert, F., Rottier, C., and Ferrier-Pagès, C. (2013). The response of the scleractinian coral Turbinaria reniformis to thermal stress depends on the nitrogen status of the coral holobiont. J. Exp. Biol. 216, 2665-2674. doi: 10.1242/jeb.085183

Berner, T., and Izhaki, I. (1994). Effect of exogenous nitrogen levels on ultrastructure of zooxanthellae from the hermatypic coral Pocillopora damicornis. Pacific Sci. 48, 254-262.

Bongiorni, L., Shafir, S., Angel, D., and Rinkevich, B. (2003). Survival, growth and gonad development of two hermatypic corals subjected to in situ fish-farm nutrient enrichment. Mar. Ecol. Prog. Ser. 253, 137-144. doi: $10.3354 /$ meps 253137

Borell, E. M., and Bischof, K. (2008). Feeding sustains photosynthetic quantum yield of a scleractinian coral during thermal stress. Oecologia 157, 593-601. doi: 10.1007/s00442-008-1102-2

Chavez, F., Strutton, P., and Friederich, G. (1999). Biological and chemical response of the equatorial Pacific Ocean to the 1997-98 El Niño. Science 80, 2126-2132. doi: 10.1126/science.286.5447.2126

Chust, G., Allen, J. I., Bopp, L., Schrum, C., Holt, J., Tsiaras, K., et al. (2014). Biomass changes and trophic amplification of plankton in a warmer ocean. Glob. Change Biol. 20, 2124-2139. doi: 10.1111/gcb.12562

Connolly, S. R., Lopez-Yglesias, M. A., and Anthony, K. R. N. (2012). Food availability promotes rapid recovery from thermal stress in a scleractinian coral. Coral Reefs 31, 951-960. doi: 10.1007/s00338-012-0925-9

Crossland, C., and Barnes, D. (1977). Nitrate assimilation enzymes from two hard corals, Acropora acuminata and Goniastrea australensis. Comp. Biochem. 57, 151-157. doi: 10.1016/0305-0491(77)90165-1

Crossland, C. J. (1987). Coral Reefs in situ release of mucus and DOC-lipid from the corals Acropora variabilis and Stylophora pistillata in different light regimes. Coral Reefs 6, 35-42. doi: 10.1007/BF00302210

Cunning, R., and Baker, A. C. (2013). Excess algal symbionts increase the susceptibility of reef corals to bleaching. Nat. Clim. Change 3, 259-262. doi: 10.1038/nclimate1711

D'Angelo, C., Hume, B. C. C., Burt, J., Smith, E. G., Achterberg, E. P., and Wiedenmann, J. (2015). Local adaptation constrains the distribution potential of heat-tolerant Symbiodinium from the Persian/Arabian Gulf. ISME J. 9, 2551-2560. doi: 10.1038/ismej.2015.80

D'Angelo, C., and Wiedenmann, J. (2012). An experimental mesocosm for long-term studies of reef corals. J. Mar. Biol. Assoc. U.K. 92, 769-775. doi: 10.1017/S0025315411001883

D'Angelo, C., and Wiedenmann, J. (2014). Impacts of nutrient enrichment on coral reefs: new perspectives and implications for coastal management and reef survival. Curr. Opin. Environ. Sustain. 7, 82-93. doi: 10.1016/j.cosust.2013.11.029

D'Elia, C. F., and Webb, K. L. (1977). The dissolved nitrogen flux of reef corals. Proc. III Int. Coral Reef Symp. 1, 325-331.

Dubinsky, Z., and Jokiel, P. L. (1994). Ratio of energy and nutrient fluxes regulates symbiosis between zooxanthellae and corals. Pacific Sci. 48, 313-324.

Dubinsky, Z., Stambler, N., Ben-Zion, M., McCloskey, L. R., Muscatine, L., and Falkowski, P. G. (1990). The effect of external nutrient resources on the optical properties and photosynthetic efficiency of Stylophora pistillata. Proc. R. Soc. B Biol. Sci. 239, 231-246. doi: 10.1098/rspb.1990.0015

Fabricius, K. E. (2005). Effects of terrestrial runoff on the ecology of corals and coral reefs: review and synthesis. Mar. Pollut. Bull. 50, 125-146. doi: 10.1016/j.marpolbul.2004.11.028

Fabricius, K. E., Cséke, S., Humphrey, C., and De’ath, G. (2013). Does trophic status enhance or reduce the thermal tolerance of scleractinian corals? A review, experiment and conceptual framework. PLOS ONE 8:e54399. doi: 10.1371/journal.pone.0054399
Falkowski, P., Dubinsky, Z., Muscatine, L., and Porter, J. W. (1984). Light and the bioenergetics of a symbiotic coral. Bioscience 34, 705-709. doi: 10.2307/1309663

Falkowski, P. G., Dubinsky, Z., Muscatine, L., and McCloskey, L. (1993). Population Control in Symbiotic Corals. Bioscience 43, 606-611. doi: $10.2307 / 1312147$

Ferrier-Pagès, C., Gattuso, J., Dallot, S., and Jaubert, J. (2000). Effect of nutrient enrichment on growth and photosynthesis of the zooxanthellate coral Stylophora pistillata. Coral Reefs 19, 103-113. doi: 10.1007/s003380000078

Ferrier-Pagès, C., Rottier, C., Beraud, E., and Levy, O. (2010). Experimental assessment of the feeding effort of three scleractinian coral species during a thermal stress: effect on the rates of photosynthesis. J. Exp. Mar. Biol. Ecol. 390, 118-124. doi: 10.1016/j.jembe.2010.05.007

Ferrier-Pagès, C., Witting, J., Tambutte, E., and Sebens, K. P. (2003). Effect of natural zooplankton feeding on the tissue and skeletal growth of the scleractinian coral Stylophora pistillata. Coral Reefs 22, 229-240. doi: 10.1007/s00338-003-0312-7

Furnas, M., Mitchell, A., Skuza, M., and Brodie, J. (2005). In the other 90\%: phytoplankton responses to enhanced nutrient availability in the Great Barrier Reef Lagoon. Mar. Pollut. Bull. 51, 253-265. doi: 10.1016/j.marpolbul.2004.11.010

Gittins, J. R., D’Angelo, C., Oswald, F., Edwards, R. J., and Wiedenmann, J. (2015). Fluorescent protein-mediated colour polymorphism in reef corals: multicopy genes extend the adaptation/acclimatization potential to variable light environments. Mol. Ecol. 24, 453-465. doi: 10.1111/mec.13041

Godinot, C., Ferrier-Pagès, C., and Grover, R. (2009). Control of phosphate uptake by zooxanthellae and host cells in the scleractinian coral Stylophora pistillata. Limnol. Oceanogr. 54, 1627-1633. doi: 10.4319/lo.2009.54.5.1627

Grottoli, A. G., Rodrigues, L. J., and Palardy, J. E. (2006). Heterotrophic plasticity and resilience in bleached corals. Nature 440, 1186-1189. doi: 10.1038/nature04565

Grover, R., Maguer, J.-F., Allemand, D., and Ferrier-Pagès, C. (2006). Urea uptake by the scleractinian coral Stylophora pistillata. J. Exp. Mar. Biol. Ecol. 332, 216-225. doi: 10.1016/j.jembe.2005.11.020

Grover, R., Maguer, J.-F., Allemand, D., and Ferrier-Pagès, C. (2008). Uptake of dissolved free amino acids by the scleractinian coral Stylophora pistillata. J. Exp. Biol. 211, 860-865. doi: 10.1242/jeb.012807

Heidelberg, K. B., Sebens, K. P., and Purcell, J. E. (2004). Composition and sources of near reef zooplankton on a Jamaican forereef along with implications for coral feeding. Coral Reefs 23, 263-276. doi: 10.1007/s00338-0040375-0

Hoegh-Guldberg, O. (1996). Nutrient enrichment and the ultrastructure of zooxanthellae from the giant clam Tridacna maxima. Mar. Biol. 125, 359-363. doi: 10.1007/BF00346316

Hoogenboom, M. O., Campbell, D. A., Beraud, E., Dezeeuw, K., and FerrierPagès, C. (2012). Effects of light, food availability and temperature stress on the function of photosystem II and photosystem I of coral symbionts. PLoS ONE 7:e30167. doi: 10.1371/journal.pone.0030167

Hoogenboom, M., Rodolfo-Metalpa, R., and Ferrier-Pagès, C. (2010). Covariation between autotrophy and heterotrophy in the Mediterranean coral Cladocora caespitosa. J. Exp. Biol. 213, 2399-2409. doi: 10.1242/jeb. 040147

Houlbrèque, F., Tambutté, E., Allemand, D., and Ferrier-Pagès, C. (2004). Interactions between zooplankton feeding, photosynthesis and skeletal growth in the scleractinian coral Stylophora pistillata. J. Exp. Biol. 207, 1461-1469. doi: 10.1242/jeb.00911

Hu, Q., Sommerfeld, M., Jarvis, E., Ghirardi, M., Posewitz, M., Seibert, M., et al. (2008). Microalgal triacylglycerols as feedstocks for biofuel production: perspectives and advances. Plant J. 54, 621-639. doi: 10.1111/j.1365313X.2008.03492.x

Hume, B., D’Angelo, C., Burt, J., Baker, A. C., Riegl, B., and Wiedenmann, J. (2013). Corals from the Persian/Arabian Gulf as models for thermotolerant reef-builders: prevalence of clade C3 Symbiodinium, host fluorescence and ex situ temperature tolerance. Mar. Pollut. Bull. 72, 313-322. doi: 10.1016/j.marpolbul.2012.11.032

Jiang, P.-L., Pasaribu, B., and Chen, C.-S. (2014). Nitrogen-deprivation elevates lipid levels in symbiodinium spp. by lipid droplet accumulation: morphological and compositional analyses. PLOS ONE 9:e87416. doi: 10.1371/journal.pone.0087416 
Johannes, R. E., Coles, S. L., and Kuenzel, N. T. (1970). The role of zooplankton in the nutrition of some scleractinian corals. Limnol. Oceanogr. 15, 579-586. doi: 10.4319/lo.1970.15.4.0579

Kopp, C., Pernice, M., Domart-Coulon, I., Djedat, C., Spangenberg, J. E., Alexander, D., et al. (2013). Highly dynamic cellular-level response of symbiotic coral to a sudden increase in environmental nitrogen. MBio 4:e00052-e00013. doi: $10.1128 /$ mbio.00052-13

Latasa, M., and Berdalet, E. (1994). Effect of nitrogen or phosphorus starvation on pigment composition of cultured Heterocapsa sp. J. Plankton Res. 16, 83-94. doi: 10.1093/plankt/16.1.83

Logan, C. A., Dunne, J. P., Eakin, C. M., and Donner, S. D. (2014). Incorporating adaptive responses into future projections of coral bleaching. Glob. Change Biol. 20, 125-139. doi: 10.1111/gcb.12390

Marubini, F., and Davies, P. (1996). Nitrate increases zooxanthellae population density and reduces skeletogenesis in corals. Mar. Biol. 127, 319-328. doi: 10.1007/BF00942117

Moberg, F., and Folke, C. (1999). Ecological goods and services of coral reef ecosystems. Ecol. Econ. 29, 215-233. doi: 10.1016/S0921-8009(99)00009-9

Msanne, J., Xu, D., Konda, A. R., Casas-Mollano, J. A., Awada, T., Cahoon, E. B., et al. (2012). Metabolic and gene expression changes triggered by nitrogen deprivation in the photoautotrophically grown microalgae Chlamydomonas reinhardtii and Coccomyxa sp. C-169. Phytochemistry 75, 50-59. doi: 10.1016/j.phytochem.2011.12.007

Muller-Parker, G., Lee, K. W., and Cook, C. B. (1996). Changes in the ultrastructure of symbiotic zooxanthellae in fed and starved sea anemones maintained under high and low light. J. Phycol. 32, 987-994. doi: 10.1111/j.00223646.1996.00987.x

Muscatine, L. (1965). Symbiosis of hydra and algae. III. Extracellular products of the algae. Comp. Biochem. Physiol. 16, 77-92. doi: 10.1016/0010406X(65)90165-9

Muscatine, L., and D'Elia, C. F. (1978). The uptake, retention and release of ammonium by reef corals. Limnol. Oceanogr. 23, 725-734. doi: 10.4319/lo.1978.23.4.0725

Muscatine, L., Falkowski, P. G., Dubinsky, Z., Cook, P. A., and McCloskey, L. R. (1989). The effect of external nutrient resources on the population dynamics of zooxanthellae in a reef coral. Proc. R. Soc. B Biol. Sci. 236, 311-324. doi: 10.1098/rspb.1989.0025

Pernice, M., Meibom, A., van den Heuvel, A., Kopp, C., Domart-Coulon, I., Hoegh-Guldberg, O., et al. (2012). A single-cell view of ammonium assimilation in coral-dinoflagellate symbiosis. ISME J. 6, 1-11. doi: 10.1038/ismej.2011.196

Rädecker, N., Pogoreutz, C., Voolstra, C. R., Wiedenmann, J., and Wild, C. (2015). Nitrogen cycling in corals: the key to understanding holobiont functioning? Trends Microbiol. 23, 490-497. doi: 10.1016/j.tim.2015.03.008

Rahav, O., Dubinsky, Z., Achituv, Y., and Falkowski, P. (1989). Ammonium metabolism in the zooxanthellate coral, Stylophora pistillata. Proc. R. Soc. Lond. B. 236, 325-337. doi: 10.1098/rspb.1989.0026

Rands, M. L., Loughman, B. C., and Douglas, A. E. (1993). The symbiotic interface in an alga-invertebrate symbiosis. Proc. R. Soc. Lond. B Biol. Sci. 253, 161-165. doi: 10.1098/rspb.1993.0097

Riegl, B., Glynn, P. W., Wieters, E., Purkis, S., d'Angelo, C., and Wiedenmann, J. (2015). Water column productivity and temperature predict coral reef regeneration across the Indo-Pacific. Sci. Rep. 5:8273. doi: 10.1038/srep 08273

Roemmich, D., and McGowan, J. (1995). Climatic warming and the decline of zooplankton in the California Current. Science 267, 1324-1326. doi: 10.1126/science.267.5202.1324

Schindelin, J., Arganda-Carreras, I., Frise, E., Kaynig, V., Longair, M., Pietzsch, T., et al. (2012). Fiji: an open-source platform for biological-image analysis. Nat. Methods 9, 676-682. doi: 10.1038/nmeth.2019

Smith, G., and Muscatine, L. (1999). Cell cycle of symbiotic dinoflagellates: variation in G1 phase-duration with anemone nutritional status and macronutrient supply in the Aiptasia pulchella-Symbiodinium pulchrorum symbiosis Mar. Biol. 134, 405-418. doi: 10.1007/s002270050557

Stambler, N., Popper, N., Dubinsky, Z., and Stimson, J. (1991). Effects of nutrient enrichment and water motion on the coral Pocillopora damicornis. Pacific Sci. $45,299-307$

Szmant, A. (2002). Nutrient enrichment on coral reefs: is it a major cause of coral reef decline? Estuaries 25, 743-766. doi: 10.1007/BF02804903
Tanaka, Y., Miyajima, T., Koike, I., Hayashibara, T., and Ogawa, H. (2006) Translocation and conservation of organic nitrogen within the coralzooxanthella symbiotic system of Acropora pulchra, as demonstrated by dual isotope-labeling techniques. J. Exp. Mar. Bio. Ecol. 336, 110-119. doi: 10.1016/j.jembe.2006.04.011

Taylor, D. L. (1968). In situ studies on the cytochemistry and ultrastructure of a symbiotic marine dinoflagellate. J. Mar. Biol. Assoc. U.K. 48, 349. doi: $10.1017 / \mathrm{s} 0025315400034548$

Titlyanov, E., Bil, K., Fomina, I., Titlyanova, T., Leletkin, V., Eden, N., et al. (2000). Effects of dissolved ammonium addition and host feeding with Artemia salina on photoacclimation of the hermatypic coral Stylophora pistillata. Mar. Biol. 137, 463-472. doi: 10.1007/s002270000370

Titlyanov, E. A., Titlyanova, T. V., Yakovleva, I. M., and Kalita, T. L. (2006). Rhythmical changes in the division and degradation of symbiotic algae in hermatypic corals. Russ. J. Mar. Biol. 32, 12-19. doi: $10.1134 /$ S1063074006010020

Tolosa, I., Treignier, C., Grover, R., and Ferrier-Pagès, C. (2011). Impact of feeding and short-term temperature stress on the content and isotopic signature of fatty acids, sterols, and alcohols in the scleractinian coral Turbinaria reniformis. Coral Reefs 30, 763-774. doi: 10.1007/s00338-011-0753-3

Tremblay, P., Grover, R., Maguer, J. F., Hoogenboom, M., and Ferrier-Pagès, C. (2014). Carbon translocation from symbiont to host depends on irradiance and food availability in the tropical coral Stylophora pistillata. Coral Reefs 33, 1-13. doi: 10.1007/s00338-013-1100-7

van Hooidonk, R., Maynard, J. A., and Planes, S. (2013). Temporary refugia for coral reefs in a warming world. Nat. Clim. Change 3, 508-511. doi: $10.1038 /$ nclimate 1829

Vaulot, D., Olson, R. J., and Merkel, S. (1987). Cell-cycle response to nutrient starvation in two phytoplankton species, Thalassiosira weissflogii and Hymenomonas carterae *. Mar. Biol. 630, 625-630. doi: 10.1007/BF00393106

Vega Thurber, R. L., Burkepile, D. E., Fuchs, C., Shantz, A. A., McMinds, R., and Zaneveld, J. R. (2014). Chronic nutrient enrichment increases prevalence and severity of coral disease and bleaching. Glob. Change Biol. 20, 544-554. doi: $10.1111 / \mathrm{gcb} .12450$

Vitova, M., Bisova, K., Kawano, S., and Zachleder, V. (2015). Accumulation of energy reserves in algae: from cell cycles to biotechnological applications. Biotechnol. Adv. 33, 1204-1218. doi: 10.1016/j.biotechadv.2015.04.012

Wang, J., and Douglas, A. (1998). Nitrogen recycling or nitrogen conservation in an alga-invertebrate symbiosis? J. Exp. Biol. 201, 2445-2453.

Wang, J. T., and Douglas, A. E. (1999). Essential amino acid synthesis and nitrogen recycling in an alga-invertebrate symbiosis. Mar. Biol. 135, 219-222. doi: 10.1007/s002270050619

Weng, L.-C., Pasaribu, B., Lin, I.-P., Tsai, C.-H., Chen, C.-S., and Jiang, P.-L. (2014). Nitrogen deprivation induces lipid droplet accumulation and alters fatty acid metabolism in symbiotic dinoflagellates isolated from Aiptasia pulchella. Sci. Rep. 4:5777. doi: 10.1038/srep05777

Wiedenmann, J., D’Angelo, C., Smith, E. G., Hunt, A. N., Legiret, F., Postle, A. D., et al. (2013). Nutrient enrichment can increase the susceptibility of reef corals to bleaching. Nat. Clim. Change 3, 160-164. doi: 10.1038/nclimate1661

Yahel, R., Yahel, G., and Genin, A. (2005). Near- bottom depletion of zooplankton over coral reefs: i: diurnal dynamics and size distribution. Coral Reefs 24, 75-85. doi: 10.1007/s00338-004-0449-z

Yellowlees, D., Rees, T. A. V., and Leggat, W. (2008). Metabolic interactions between algal symbionts and invertebrate hosts. Plant Cell Environ. 31, 679-694. doi: 10.1111/j.1365-3040.2008.01802.x

Yonge, C. M. (1930). Studies on the physiology of corals. I. Feeding mechanisms and food. Sci. Rep. Great Barrier Reef Exped. 1, 13-57.

Conflict of Interest Statement: The authors declare that the research was conducted in the absence of any commercial or financial relationships that could be construed as a potential conflict of interest.

Copyright (c) 2015 Rosset, D'Angelo and Wiedenmann. This is an open-access article distributed under the terms of the Creative Commons Attribution License (CC BY). The use, distribution or reproduction in other forums is permitted, provided the original author(s) or licensor are credited and that the original publication in this journal is cited, in accordance with accepted academic practice. No use, distribution or reproduction is permitted which does not comply with these terms. 